\title{
Evaluasi Penerapan Sistem Akuntansi Pendapatan Pada Badan Keuangan Daerah Kota Lubuklinggau
}

\author{
Miki Indika, Abdika Jaya \& Novi Septianah \\ Fakultas Ekonomi Universitas Musi Rawas \\ Email: miki.unmura@gmail.com
}

\begin{abstract}
The aim of this study is to evaluate the application of an income accounting system to the Regional Finance Body of Lubuklinggau City. It is descriptive research; this research is not intended to test hypotheses but only systematically describes the facts, situations, and activities of the accounting system of income in the Regional Finance Agency of the City of Lubuklinggau. Operational variables of this study are income accounting systems with related party indicators, related documents, and accounting systems and procedures. Secondary data is in the form of body profiles and reports on the realization of regional revenue and expenditure budgets. The data analysis technique used descriptive analysis. The results of the study showed that the income accounting system at the Lubuklinggau City Regional Finance Body for related parties is not appropriate with Government Regulation Number 71 of 2010, PERMENDAGRI Number 64 of 2013, and Regulation of Lubuklinggau Mayor, Number 63 of 2016 and Regulation Lubuklinggau Mayor Number 32 of 2012.It had been already referring to Government Regulation Number 71 of 2010 concerning Regional Financial Management Guidelines, and for related documents and systems and procedures for accounting income in accordance with Government Regulation Number 71 of 2010, PERMENDAGRI Number 64 of 2013, Regulation of Mayor of Lubuklinggau Number 63 of 2016 and Regulation of Mayor Lubuklinggau Number 32 of 2012.
\end{abstract}

Keywords: income accounting systems, related parties, related documents, systems and accountingprocedures

\section{Pendahuluan}

Standar Akuntansi Pemerintahan merupakan salah satu aspek penting yang diperlukan untuk meningkatkan kualitas tata kelola keuangan negara dan pelaporan keuangan pemerintahan. Terdapat banyak pihak yang berkepentingan dengan standar akuntansi pemerintahan antara lain penyaji laporan keuangan, auditor, masyarakat pengguna laporan keuangan, organisasi profesi akuntansi, akademis, dan pemerintah. Standar akuntansi pemerintahan perlu dikembangkan untukmemperbaiki praktik akuntansi keuangan pada lingkungan organisasi pemerintahan. (Mahmudi, 2013)

Menurut Mahmudi (2013) Sistem Akuntansi Pemerintah Daerah (SAPD) adalah serangkaian prosedur manual maupun terkomputerisasi mulai dari perkumpulan data, pencatatan, pengikhtisaran sampai dengan pelaporan posisi keuangan dan operasi keuangan pemerintah daerah. Sistem Akuntansi Pemerintah Daerah terdiri dari dua bagian yaitu Sistem Akuntansi Bendahara Umum Daerah pada atuan Kerja Pengelola Keuangan Daerah (SKPKD) dan Sistem Akuntansi Instansi pada Satuan Kerja Perangkat Daerah (SKPD).

Menurut Peraturan Walikota Lubuklinggau Nomor 63 Tahun 2016 tentang Sistem Akuntansi Pemerintah Daerah. Sistem Akuntansi Pemerintah Daerah (SAPD) adalah

Published by:

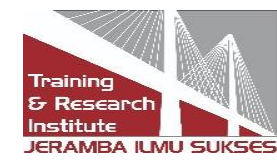


rangkaian sistematis dari prosedur, penyelenggara, peralatan, dan elemen lain untuk mewujudkan fungsi akuntansi sejak analisis transaksi sampai dengan pelaporan keuangan di lingkungan organisasi pemerintah Kota Lubuklinggau.

Akuntansi pemerintahan merupakan bagian dari disiplin ilmu akuntansi yang baru berkembang di Indonesia akhir-akhir ini, perkembangan akuntansi pemerintahan secara umum di seluruh negara juga sudah berkembang melalui suatu penerapan sistem akuntansi keuangan daerah sesuai Standar Akuntansi pemerintahan (SAP), yang di atur dalam peraturan pemerintah Nomor 25 tahun 2004 dan selanjutnya di ganti dengan PP Nomor 71 Tahun 2010.

Peraturan Pemerintah Nomor 71 Tahun 2010 dijelaskan bahwa sistem akuntansi pemerintah pada Pemerintah Pusat diatur dengan Peraturan Menteri Keuangan yang mengacu pada Pedoman Umum Sistem Akuntansi Pemerintah setelah berkoordinasi dengan Menteri Dalam Negeri, sedangkan sistem akuntansi pemerintah pada pemerintah daerah diatur dengan Peraturan Gubernur / Bupati / Walikota yang mengacu pada Pedoman Umum Sistem Akuntansi Pemerintah. Sistem Akuntansi Pemerintahan Daerah (SAPD) disusun dengan Peraturan Daerah dengan berpedoman pada prinsip pengendalian internal sesuai dengan Peraturan Pemerintah yang mengatur tentang pengendalian internal dan Peraturan Pemerintah tentang Standar Akuntansi Pemerintah.

Lingkup pengaturan PP Nomor 71 Tahun 2010 adalah meliputi SAP Berbasis Akrual dan SAP Berbasis Kas Menuju Akrual. SAP Berbasis Kas Menuju Akrual dapat berlaku selama masa transisi bagi entitas yang belum siap untuk menerapkan SAP Berbasis Akrual. Walaupun entitas pelaporan untuk sementara masih diperkenankan menerapkan SAP Berbasis Kas Menuju Akrual, entitas pelaporan diharapkan dapat segera menerapkan SAP Berbasis Akrual. Untuk percepatan penerapan SAP berbasis akrual di pemerintah daerah, maka ditetapkan Peraturan Menteri Dalam Negeri Republik Indonesia Nomor 64 Tahun 2013 tentang Penerapan Standar Akuntansi Pemerintahan Berbasis Akrual pada Pemerintah Daerah.

Sesuai dengan Permendagri Nomor 64 Tahun 2013 disebutkan bahwa laporan keuangan dapat dikatakan andal jika informasi dalam laporan keuangan tersebut menyajikan setiap fakta secara jujur serta dapat diverifikasi. Laporan keuangan yang handal tersebut dapat tercapai dengan adanya sistem yang baik. Karakteristik yang menjadi prasyarat normatif yang diperlukan agar laporan keuangan pemerintah dapat memenuhi kualitas yang dikehendaki yaitu relevan, andal, dapat dibandingkan, dan dapat dipahami. Laporan keuangan dikatakan relevan apabila laporan keuangan dapat menjadi pertimbangan dalam proses pengambilan keputusan. Ketepatan waktu dalam penyampaian laporan keuangan sangat penting bagi tingkat manfaat dan nilai laporan tersebut.

Menurut Muindro (2013) Pemerintah Daerah adalah pelaksanaan fungsi-fungsi pemerintahan daerah yang dilakukan oleh lembaga pemerintahan daerah yaitu Pemerintah Daerah dan Dewan Perwakilan Rakyat Daerah (Pemda dan DPRD). Kepala Daerah dan Wakil Kepala Daerah dipilih secara langsung secara demokratis. Hubungan antara Pemerintah Daerah dan DPRD merupakan hubungan kerja yang kedudukannya setara dan bersifat kemitraan, sama dan sejajar. Dalam penyelenggaraan pemerintah daerah, kepala daerah dibantu oleh perangkat daerah yang terdiri dari unsur staf yang membantu penyusunan kebijakan dan koordinasi, diwadahi dalam lembaga sekretariat,

Published by: 
unsur pendukung tugas kepala daerah dalam penyusunan pelaksanaan kebijakan daerah yang bersifat spesifik diwadahi dalam lembaga teknis daerah serta pelaksana urusan daerah yang diwadahi dalam lembaga dinas daerah, salah satu bentuk lembaga dinas daerah adalah Badan Keuangan Daerah (BKD).

Menurut Indra (2010) pendapatan (income) meliputi seluruh pendapatan (revenues). Pendapatan timbul dalam pelaksanaan aktivitas organisasi sektor publik yang biasa dan dikenal dengan sebutan fundraising. Pendapatan LRA adalah semua penerimaan Rekening Kas Umum Negara/Daerah yang menambah Saldo Anggaran Lebih dalam periode tahun anggaran yang bersangkutan yang menjadi hak pemerintah, dan tidak perlu dibayar kembali oleh pemerintah. Pendapatan LO adalah hak pemerintah pusat/daerah yang diakui sebagai penambah ekuitas dalam periode tahun anggaran yang bersangkutan dan tidak perlu dibayar kembali. (Abdul dan Syam, 2012).

Menurut Peraturan Menteri Dalam Negeri Republik Indonesia Nomor 59 Tahun 2007 Penerimaan Daerah adalah uang yang masuk ke kas daerah. Pengeluaran Daerah adalah uang yang keluar dari kas daerah. Pendapatan Daerah adalah hak pemerintah daerah yang diakui sebagai penambah nilai kekayaan bersih. Pasal 24 menyebutkan Pendapatan daerah meliputi semua penerimaan uang melalui rekening kas umum daerah, yang menambah ekuitas dana, merupakan hak daerah dalam satu tahun anggaran dan tidak perlu dibayar kembali oleh daerah. Pasal 25 menyebutkan Pasal 25 Pendapatan daerah sebagaimana dimaksud dalam Pasal 22dikelompokan atas: a) pendapatan asli daerah; b) dana perimbangan; dan c) lain-lain pendapatan daerah yang sah. Pasal 26 Pasal 26 Kelompok pendapatan asli daerah dibagi menurut jenis pendapatan yang terdiri atas: a) pajak daerah; b) retribusi daerah; c) hasil pengelolaan kekayaan daerah yang dipisahkan; dan d) lain-lain pendapatan asli daerah yang sah.

Menurut Peraturan Walikota Lubuklinggau Nomor 63 Tahun 2016 (2016) Akuntansi pendapatan pada lingkup SKPD dilakukan hanya untuk mengetahui, mencatat, dan melaporkan Pendapatan Asli Daerah (PAD) yang berada dalam wewenang SKPD. Pendapatan tersebut terdiri dari pendapatan pajak, pendapatan retribusi, pendapatan hasil pengelolaan kekayan daerah yang dipisahkan dan lain-lain PAD yang sah.

Pemerintah atau unit kerja pemerintah perlu menggunakan sistem akuntansi, dimana dengan adanya penerapan sistem akuntansi akan dapat memudahkan manajemen untuk menyediakan informasi keuangan, serta memudahkan pengelolaan keuangan suatu organisasi. Salah satunya yakni Sistem Akuntansi Sektor Publik, dimana Akuntansi Pemerintahan merupakan salah satu bagiannya. Peran utama akuntansi dalam sektor publik yaitu menyediakan informasi akuntansi yang akan digunakan oleh manajer sektor publik dalam melakukan fungsi perencanaan dan pengendalian organisasi. Informasi akuntansi diberikan sebagai alat atau sarana untuk membantu manajer menjalankan fungsi-fungsi manajemen sehingga tujuan organisasi dapat tercapai.

Badan Keuangan Daerah Kota Lubuklinggau merupakan unsur pelaksana pemerintah daerah yang di dalam pelaksanaan tugasnya berada sepenuhnya dan bertanggung jawab kepada kepala daerah. Menurut Peraturan Walikota Lubuklinggau Nomor 34 Tahun 2016 yang dimaksud dengan Badan adalah Badan Keuangan Daerah Kota Lubuklinggau.

Badan merupakan unsur penunjang urusan pemerintahan yang menjadi wewenang daerah

Published by:

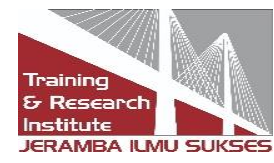


di bidang pengelolaan keuangan, pendapatan dan aset daerah. Badan dipimpin oleh seorang Kepala Badan yang berada di bawah dan bertanggung jawab kepada Walikota melalui Sekretaris Daerah. Badan mempunyai tugas membantu Walikota melaksanakan kewenangan Daerah di bidang pengelola keuangan, pendapatan dan aset daerah serta melaksanakan tugas pembantuan yang diberikan oleh pemerintah dan/atau Pemerintah Provinsi. Badan Keuangan Daerah mempunyai fungsi sebagai berikut: a) perumusan kebijakan teknis, fasilitas, koordinasi serta pembinaan teknis dibidang pengelola keuangan, pendapatan dan aset daerah; b) pelaksanaan kebijakan dibidang pengelola keuangan, pendapatan dan aset daerah; c) pelaksanaa evaluasi dan pelaporan dibidang pengelola keuangan, pendapatan dan aset daerah; d) pelaksanaan administrasi dan pembinaan teknis penyelenggaraan fungsi- fungsi penunjang di bidang pengelola keuangan, pendapatan dan aset daerah sesuai dengan lingkup tugasnya; dan e) pelaksanaan fungsi lain yang diberikan oleh Walikota terkait dengan tugas dan fungsinya. Adapun tugas pokok dan fungsi Badan Keuangan Daerah Kota Lubuklinggau dalam melaksanakan segala usaha dan kegiatan pemungutan, pengumpulan dan pemasukan pendapatan daerah ke kas daerah.

Wewenang dilimpahkan oleh kepala daerah Kota Lubuklinggau kepada Kepala Badan Keuangan Daerah Kota Lubuklinggau itu adalah wewenang untuk mengambil tindakantindakan pembebanan dan pemungutan pendapatan daerah yang berwujud pengeluaran Surat Ketetapan Pajak (SKP), Surat Paksa (SP), dan penagihan- penagihan pendapatan daerah sesuai dengan peraturan daerah tantang pajak dan/atau retribusi serta peraturanperaturan pendapatan daerah yang bersangkutan.

Penerapan sistem akuntansi pendapatan pada Badan Keuangan Daerah Kota Lubuklinggau pada dasarnya telah berjalan sesuai dengan peraturan perundang-undangan yang berlaku. Akan tetapi dalam pelaksanaannya masih ditemukan kendala yang menghambat jalannya kegiatan akuntansi pemerintahan baik itu disebabkan oleh birokrasi (hubungan hirarki yang terkait dalam sistem akuntansi pendapatan) yang berlaku atau kesalahan manusia (human error). Kendala-kendala yang ditemukan misalnya, adanya beberapa masalah yang berkaitan dengan upaya merealisasikan target pendapatan daerah karena belum maksimalnya kompetensi aparatur pengelola pajak, dan belum optimalnya sistem pengelolaan pendapatan daerah. Dengan adanya berbagai kendala- kendala di lingkup Badan Keuangan Daerah Kota Lubuklinggau tersebut maka peneliti tertarik ingin mengetahui sejauh mana pelaksanaan sistem akuntansi pendapatan SKPD pada Badan Keuangan Daerah Kota Lubuklinggau sekarang ini, apakah benar- benar sudah mengacu pada Peraturan Walikota Lubuklinggau No. 63 Tahun 2016 tentang Sistem Akuntansi Pemerintah Daerah dan Peraturan Pemerintah No. 71 Tahun 2010 tentang Pedoman Pengelolaan Keuangan Daerah. karena kalau belum sesuai dengan peraturan yang ada akan berdampak terhadap sistem akuntansi pendapatan yang ada dan akan berpengaruh terhadap pengelolaan keuangan daerah. Berdasarkan uraian latar belakang diatas maka peneliti mengambil judul penelitian "Evaluasi Penerapan Sistem Akuntansi Pendapatan Pada Badan Keuangan Daerah Kota Lubuklinggau".

\section{Tinjauan Literatur}

Published by:

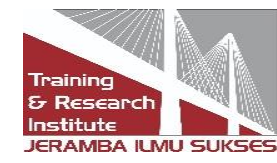




\subsection{Unsur-unsur Sistem Akuntansi}

Menurut Peraturan Walikota Lubuklinggau Nomor 63 Tahun 2016. Sistem akuntansi mencakup teknik pencatatan, pengakuan dan pengungkapan atas pendapatan-LO, pendapatan-LRA, belanja, aset, kewaiban, ekuitas, penyesuaian dan koreksi serta penyusunan laporan keuangan SKPD. Sistem akuntansi SKPD terdiri dari sistem akuntansi pokok sebagai berikut:

1). Sistem Akuntansi Pendapatan

2). Sistem Akuntansi Beban dan Belanja

3). Sistem Akuntansi Kas dan Setara Kas

4). Sistem Akuntansi Piutang

5). Sistem Akuntansi Persediaan

6). Sistem Akuntansi Aset Tetap

7). Sistem Akuntansi Aset Lainnya

8). Sistem Akuntansi Koreksi Kesalahan

9). Proses Akuntansi dan Pembuatan Laporan Keuangan

Menurut Mulyadi (2013) unsur suatu sistem akuntansi pokok adalah formulir, catatan yang terdiri dari jurnal, buku besar dan buku pembantu, serta laporan. Menurut Mahmudi (2013) unsur sistem akuntansi pemerintahan terdiri dari pelaksana sistem akuntansi, dkumen yang digunakan, buku catatan akuntansi, dan prosedur akuntansi.

Menurut Mahmudi (2013) sistem akuntansi penerimaan kas adalah serangkaian proses mulai pencatatan, penggolongan, dan peringkasan transakasi dan/atau kejadian keuangan serta pelaporan keuangan dalam rangka pertanggungjawaban pelaksanaan APBD yang berkenaan dengan penerimaan kas pada SKPD dan /atau SKPKD yang dapat dilaksanakan secara manual maupun komputerisasi. Unsur pokok sistem akuntansi penerimaan kas adalah sebagai berikut:

a). Pelaksana

Pelaksana sistem akuntansi penerimaan kas adalah sebagai berikut:

1). Tingkat SKPD dilaksanakan oleh PPK-SKPD (Pejabat Penatausahaan Keuangan

Satuan Kerja Perangkat Daerah), Bendahara penerimaan Pembantu.

2). Tingkat SKPD dilaksanakan oleh PPKD (Pejabat Pengelola Keuangan Daerah) fungsi akuntansi, Bendahara Penerimaan, Bendahara Penerimaan Pembantu.

b). Dokumen

Dokumen yang digunakan dalam sistem akuntansi penerimaan kas antata lain

1). Surat Ketetapan Pajak daerah (SKPD)

2). Surat Ketetapan Retribusi (SKR)

3). Surat Tanda Setoran

Published by: 
4). Surat Tanda Bukti Penerimaan (STBP)

5). Nota Kredit

6). Bukti Transfer

7). Dokumen Lainnya.

c). Catatan Akuntansi

Buku catatan akuntansi yang digunakan dalam sitem akuntansi peneriman kas meliputi:

1). Buku Jurnal Penerimaan Kas

2). Buku Kas Umum

3). Buku Rekapitulasi Penerimaan Harian

4). Buku Besar Kas

5). Buku Besar Pembantu Penerimaan Kas

6). Prosedur Akuntansi Penerimaan Kas

Sistem dan prosedur akuntansi penerimaan kas terdiri dari dua bagian yaitu sistem dan prosedur akuntansi penerimaan kas di Satuan Kerja Perangkat Daerah (SKPD) dan sistem dan prosedur akuntansi penerimaan kas di Satuan Kerja Pengelola Keuangan Daerah (SKPKD). Sistem dan prosedur Penatausahaan Penerimaan Kas di SKPD, terdiri:

1). Sistem dan prosedur penatausahaan penerimaan kas dari pajak dan retribusi daerah melalui Bendahara Penerimaan.

2). Sistem dan prosedur penatausahaan penerimaan kas dari pajak dan retribusi daerah melalui Bendahara Penerimaan Pembantu.

3). Sistem dan prosedur penatausahaan penerimaan kas dari pajak dan retribusi daerah melalui Badan, Lembaga Keuangan, atau Kantor Pos yang ditunjuk oleh pemerintah daerah.

Sistem dan prosedur Akuntansi Penerimaan Kas di SKPKD merupakan kelanjutan dari sistem dan prosedur penatausahaan kas di SKPD yang kemudian diverifikasi dan dicatat kedalam buku jurnal penerimaan kas, buku besar dan buku pembantu.

Menurut Mahmudi (2013) sistem akuntansi pengeluaran kas adalah serangkaian proses mulai pencatatan, penggolongan, dan peringkasan transakasi dan/atau kejadian keuangan serta pelaporan keuangan dalam rangka pertanggungjawaban pelaksanaan APBD yang berkenaan dengan pengeluaran kas pada SKPD dan /atau SKPKD yang dapat dilaksanakan secara manual maupun komputerisasi. Unsur pokok sistem akuntansi pengeluaran kas adalah sebagai berikut:

a). Pelaksana

Pelaksana sistem akuntansi pengeluaran kas adalah sebagai berikut:

1). Tingkat SKPD dilaksanakan oleh PPK-SKPD (Pejabat Penatausahaan Keuangan

Published by: 
Satuan Kerja Perangkat Daerah), dan Bendahara Pengeluaran.

2). Tingkat SKPD dilaksanakan oleh PPKD (Pejabat Pengelola Keuangan Daerah)

Fungsi akuntansi, Bendahara Pengeluaran.

b). Dokumen

Dokumen yang digunakan dalam sistem akuntansi pengeluaran kas antata lain

1). Surat Perintah Pencairan Dana (SP2D)

2). Surat Pertanggungjawaban (SPJ)

3). Nota Debet

4). Bukti Transfer

5). Dokumen Lainnya

c). Catatan Akuntansi

Buku catatan akuntansi yang digunakan dalam sitem akuntansi pengeluaran kas meliputi:

1). Buku Jurnal Pengeluaran Kas

2). Buku Kas Umum

3). Buku Besar Kas

4). Buku Besar Pembantu Pengeluaran Kas

\subsection{Prosedur Akuntansi Pengeluaran Kas}

Prosedur akuntansi pengeluaran kas dilakukan melalui mekanisme:

1). Penerbitan SP2D Langsung (LS)

2). Penerbitan SP2D Uang Persediaan (UP)

3). Penerbitan SP2D Ganti Uang (GU)

4). Penerbitan SP2D Tambahan Uang Persediaan (TU)

Mekanisme penerbitan SP2D baik LS, UP, GU, dan TU didahului dengan proses penatausahaan ditingkat SKPD berupa pengajuan Surat Permintaan Pembayaran (SPP) oleh bendahara pengeluaran, Pengajuan SPP harus didukung oleh dokumen-dokumen terkait, antara lain:

(a).Salinan Surat Penyediaan Dana (SPD)

(b).Surat Pengantar SPP LS/UP/GU/TU

(c).Ringkasan SPP LS/UP/GU/TU

(d).Rincian Penggunaan SPP LS/UP/GU/TU

(e).Surat Pernyataan oleh Pengguna Anggaran/Kuasa Pengguna Anggaran - khusus untuk pengajuan SPP UP/GU/TU

(f). Lampiran lainnya yang diperlukan.

Published by: 
Setelah SPP yang diajukan bendahara pengeluaran diverifikasi dan dinyatakan lengkap oleh PPK-SKPD, tahap berikutnya adalah Pengguna Anggaran menerbitkan Surat Perintah Membayar (SPM) sesuai dengan jenis SPP yang diajukan. Dengan demikian terdapat SPM LS/UP/GU/TU. SPM LS/UP/GU/TU selanjutnya diajukan ke Bendahara Umum Daerah (BUD) untuk dimintakan penerbitan SP2D LS/UP/GU/TU. SP2D berfungsi seperti cek yang dapat digunakan untuk mencairkan dana yang ditunjuk pemerintah daerah.

\subsection{Sistem Akuntansi Pemerintah Daerah}

a. Pemerintah Daerah

Menurut Muindro (2013) pemerintah daerah dalam rangka meningkatkan efisiensi dan efektivitas penyelenggaraan otonomi daerah, perlu memperhatikan hubungan antar susunan pemerintahan dan antar pemerintahan daerah, potensi dan keanekaragaman daerah.

Menurut Muindro (2013) pemerintah daerah adalah pelaksanaan fungsi-fungsi pemerintahan daerahyang dilakukan oleh lembaga pemerintahan daerah yaitu Pemerintah Daerah dan Dewan Perwakilan Rakyat Daerah (Pemda dan DPRD). Kepala Daerah dan Wakil Kepala Daerah dipilih secara langsung dan demokratis. Hubungan antara Pemerintah Daerah dan Dewan Perwakilan Rakyat Daerah merupakan hubungan kerja yang kedudukannya setara dan bersifat kemitraan, sama dan sejajar. Dalam penyelenggaraan pemerintah daerah, kepala daerah dibantu oleh perangkat daerah. Secara umum perangkat daerah terdiri dari staf yang membantu penyusunan kebijakan dan koordinasi, diwadahi dalam lembaga sekretariat; unsur pendukung tugas kepala daerah dalam penyusunan pelaksanaan kebijakan daerah yang bersifat spesifik diwadahi dalam lembaga teknis daerah; serta unsur pelaksana urusan daerah yang diwadahi dalam lembaga dinas daerah.

Menurut Abdul dan Syam (2012) pemerintah daerah adalah kepala daerah beserta perangkat lainnya, sebagai badan eksekutif, sedangkan DPRD sebagai badan legislatif. Menurut Peraturan Menteri Dalam Negeri Republik Indonesia Nomor 64 Tahun 2013 Pemerintah daerah adalah pemrintah provinsi dan pemerintah kabupaten/kota.

Menurut Muindro (2013) sesuai dengan Undang-undang Dasar Negara Republik Indonesia Tahun 1945, pemerintah daerah berwenang untuk mengatur dan mengurus sendiri urusan pemerintahan menurut asas otonomi dan tugas pembantuan. Pemberian otonomi luas kepada daerah diarahkan untuk mempercepat terwujudnya kesejahteraan masyarakat melalui peningkatan pelayanan, pemberdayaan dan peran serta masyarakat. Disamping itu melalui otonomi luas, daerah diharapkan mampu meningkatkan daya saing dengan memperhatikan prinsip demokrasi, pemerataan, keadilan, keistimewaan dan kekhususan serta potensi dan keanekaragaman daerah dalam Sistem Negara Kesatuan Republik Indonesia.

b. Fungsi Pemerintah Daerah

Menurut penelitian Jeane, Hendrik dan Victoria (2015) fungsi pemerintah daerah menurut Undang-undang Republik Indonesia No.32 Tahun 2004 adalah:

Published by:

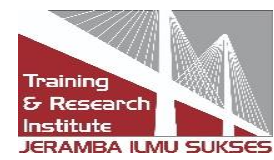


1). Pemerintah darah mengatur dan mengurus sendiri urusan pemerintahan menurut asas otonomi dan tugas pembantuan.

2).Menjalankan otonomi seluas-luasnya, kecuali urusan pemerintahan dengan tujuan meningkatkan kesejahteraan masyarakat, pelayanan umum dan dayasaing daerah.

3). Pemerintah daerah delam menyelenggarakan urusan pemerintah memiliki hubungan pemerintahan pusat dengan pemerintahan daerah. Dimana hubungan tersebut meliputi wewenang, keuangan, pelayanan umum pemanfaatan sumber daya alam dan sumber daya lainnya.

Pemerintah daerah dalam rangka meningkatkan efisiensi dan efektivitas penyelenggaraan otonomi daerah, perlu memperhatikan hubungan antar susunan pemerintahan dan antar pemerintahan daerah, potensi dan keanekaragaman daerah. Aspek hubungan wewenang memperhatikan kekhususan dan keragaman daerah dalam Sistem Negara Kesatuan Republik Indonesia. Aspek hubungan keuangan, pelayanan umum, pemanfaatan sumber daya alam, dan sumber daya lainnya dilaksanakan secara adil dan selaras. Agar mampu menjalankan peran tersebut, daerah diberikan kewenangan yang seluas-luasnya disertai dengan pemberian hak dan kewajiban menyelenggarakan otonomi daerah dalam kesatuan sistem penyelenggaraan pemerintahan negara.

Menurut Muindro (2013) hak dan kewajiban Daerah, dalam menyelenggarakan otonomi, daerah mempunyai hak:

1). Mengatur dan mengurus sendiri urusan pemerintahannya

2). Memilih pimpinan daerah

3). Mengelola aparatur Negara

4).Mengelolan kekayaan daerah

5).Memungut pajak daerah dan retribusi daerah

6).Mendapatkan bagi hasil dari pengelolaan sumber daya alam dan sumber daya lainnya yang berada di daerah.

7). Mendapatkan sumber pendapatan lain yang syah, dan

8). Mendapatkan hak lainnya yang diatur dalam peraturan perundang-undangan. Menurut Muindro (2013) akuntansi keuangan daerah adalah akuntansi yang dipakai oleh Pemerintah Daerah, untuk melakukan manajemen dan pengelolaan keuangan daerah. Manajemen keuangan daerah merupakan alat untuk mengurus dan mengatur rumah tangga pemerintah daerah. Akuntansi keuangan daerah merupakan salah satu bidang dalam akuntansi sektor publik yang mendapat perhatian besar dari berbagai pihak semenjak reformasi.

Menurut Mahmudi (2013) Sistem akuntansi pemerintahan meliputi Sistem Akuntansi Pemerintah Pusat (SAPP) dan Sistem Akuntansi Pemerintah Daerah (SAPD). Sistem akuntansi pemerintah berbeda dengan standar akuntansi pemerintahan (SAP) namun keduanya saling terkait. Standar akuntansi merupakan prinsip-prinsip akuntansi yang menjadi pedoman dalam menyusun dan menyajikan laporan keuangan. Standar

Published by: 
akuntansi mengatur mengenai keluaran yang diharapkan, sedangkan sistem akuntansi merupakan cara atau teknologi untuk menghasilkan keluaran sesuai dengan standar akuntansi.

Menurut Peraturan Menteri Dalam Negeri Republik Indonesia Nomor 64 Tahun 2013 Sistem Akuntansi Pemerintah Daerah yang selanjutnya disingkat SAPD adalah rangkaian sistematik dari prosedur, penyelenggara, peralatan dan elemen lain untuk mewujudkan fungsi akuntansi sejak analisis transaksi sampai dengan pelaporan keuangan dilingkungan organisasi pemerintahan daerah.

Menurut Peraturan Walikota Lubuklinggau Nomor 63 Tahun 2016. Standar Akuntansi Pemerintahan selanjutnya disingkat SAP adalah prinsip-prinsip akuntansi yang diterapkan dalam menyusun dan menyajikan laporan keuangan pemerintah. Sistem Akuntansi Pemerintahan Daerah yang selanjutnya disingkat SAPD adalah rangkaian sistematik dari prosedur, penyelenggara, peralatan, dan elemen lain untuk mewujutkan fungsi akuntansi sejak analisis transaksi sampai dengan pelaporan keuangan di lingkuangan organisasi pemerintah Kota Lubuklinggau.

Menurut Mahmudi (2013) Sistem Akuntansi Pemerintah Daerah (SAPD) adalah serangkaian prosedur manual maupun terkomputerisasi mulai dari perkumpulan data, pencatatan, pengikhtisaran sampai dengan pelaporan posisi keuangan dan operasi keuangan pemerintah daerah. Sistem Akuntansi Pemerintah Daerah terdiri dari dua bagian yaitu Sistem Akuntansi Bendahara Umum Daerah pada Satuan Kerja Pengelola Keuangan Daerah (SKPKD) dan Sistem Akuntansi Instansi pada Satuan Kerja Perangkat Daerah (SKPD).

\subsection{Sistem Akuntansi Pendapatan}

Menurut Peraturan Walikota Lubuklinggau Nomor 63 Tahun 2016 (2016) Akuntansi pendapatan pada lingkup SKPD dilakukan hanya untuk mengetahui, mencatat, dan melaporkan Pendapatan Asli Daerah (PAD) yang berada dalam wewenang SKPD. Pendapatan tersebut terdiri dari pendapatan pajak, pendapatan retribusi, pendapatan hasil pengelolaan kekayan daerah yang dipisahkan dan lain-lain PAD yang sah. Adapun lain-lain PAD yang sah meliputi penerimaan kas hasil penjualan kekayaan daerah yang tidak dipisahkan, jasa giro, pendapatan jasa bunga deposito, penerimaan atas tuntutan ganti kerugian daerah, penerimaan komisi, potongan ataupun bentuk lain sebagai akibat dari penjualan dan/atau pengadan barang dan/atau jasa oleh daerah, penerimaan keungtungan dari selisih nilai tukar rupiah terhadap mata uang asing, pendapatan denda atas keterlambatan palaksanaan pekerjaan, pendapatan denda pajak, pendapatan retribusi, pendapatan hasil eksekusi atas jaminan, pendapatan dari penyelenggaraan pendidikan dan pelatihan, pendapatan hasil pemanfaatan kekayaan daerah dan pendapatan dari angsuran/cicilan penjualan.

\section{1) Pihak Yang Terkait}

Pihak yang terkait dalam sistem akuntansi pendapatan pada SKPD adalah Pengguna Anggaran/Kuasa Pengguna Anggaran (PA/KPA), Pejabat Penatausahaan keuangan SKPD (PPK-SKPD), Bendahara Penerimaan SKPD, Bendahara Umum Daerah (BUD), dan Pihak Ketiga.

Published by: 


$\begin{aligned} & \text { Pengguna Anggaran/Kuasa } \\ & \text { Menandatangani/memisahkan Pengguna }\end{aligned}$
$\begin{aligned} & \text { daerah/dokumen lain yang dipersamakan; }\end{aligned}$

1) Pejabat Penatausahaan Keuangan SKPD (PPK-SKPD);

a) Mencatat transaksi/kejadian pendapatan LO dan pendapatan LRA berdasarkan bukti-bukti transaksi yang sah dan valid ke Buku Jurnal LRA dan Buku Jurnal LO dan Neraca;

b) Melakukan penyesuaian di akhir tahun terhadap dokumen pendapatan yang belum diterima pembayarannya;

c) Melakukan penyesuaian di akhir tahun terhadap dokumen pendapatan yang penerimaan yang melewati periode diterbitkannya dokumen pendapatan.

2) Bendahara Penerimaan SKPD

a) Mencatat dan membukukan semua penerimaan pendapatan ke dalam buku kas penerimaan;

b) Melakukan penyetoran uang yang diterima ke kas daerah setiap hari.

3) Bendahara Umum Daerah (BUD);

Menerima realisasi pendapatan yang dibayarkan baik oleh pihak ketiga ataupun melalui bendahara penerimaan.

\section{4) Pihak Ketiga}

Pihak ketiga disini adalah Wajib Pajak, Wajib Retribusi, atau pihak lainnya yang terkait dengan penerimaan pendapatan.

\section{2). Dokumen Terkait}

Dokumen yang terkait dalam prosedur akuntansi Pendapatan LO dan PendapatanLRA secara umum dikelompokkan sebagai berikut:

1) Surat Ketetapan Pajak Daerah (SKP-Daerah)

2) Surat Ketetapan Retrebusi Daerah (SKRD), Karcis dan sejenisnya

3) Tanda Bukti Penerimaan (TBP)

4) Surat Tanda Setoran ( STS)

5) Bukti transfer / setor

6) Nota kredit bank

7) Bukti Memorial

8).Bukti transaksi penerimaan kas lainnya

\subsection{Sistem dan Prosedur Pengelolaan Penerimaan Pendapatan}

Menurut Peraturan Walikota Lubuklinggau Nomor 32 Tahun 2012 tentang Sistem dan prosedur pengelolaan keuangan untuk penerimaan pendapatan pada Badan Keuangan Daerah Kota Lubuklinggau adalah sebagai berikut: 
a) Umum

1) Penerimaan daerah disetor ke rekening kas umum daerah pada bank pemerintah yang ditunjuk dan dianggap sah setelah BUD/Kuasa BUD menerima nota kredit.

2) Penerimaan daerah yang disetor ke rekening kas umum daerah, dilakukan dengan cara:

(a) Disetor langsung ke bank oleh pihak ketiga, wajib pajak atau wajib retribusi

(b) Disetor melalui bank lain, atau badan, lembaga keuangan dan/atau kantor pos oleh pihak ketiga, wajib pajak atau wajib retribusi; dan

(c) Disetor melalui bendahara penerimaan oleh pihak ketiga, wajib pajak atau wajib retribusi.

3). Benda berharga seperti karcis retribusi sebagai tanda bukti pembayaran oleh pihak ketiga kepada bendahara penerimaan diterbitkan dan disahkan oleh PPKD.

2) Penatausahaan Bendahara Penerimaan

1) Bendahara penerimaan wajib menyelenggarakan penatausahaan terhadap seluruh penerimaan dan penyetoran atas penerimaan yang menjadi tanggung jawabnya.

2) Bendahara penerimaan SKPD bertugas untuk menerima, menyimpan, menyetorkan, menatausahakan, dan mempertanggungjawabkan penerimaan pendapatan dalam rangka pelaksanaan APBD pada SKPD.

3) Untuk melaksanakan tugas diatas bendahara penerimaan SKPD berwenang:

(a) Menerima penerimaan yang bersumber dari pendapatan asli daerah;

(b) Menyimpan seluruh penerimaan;

(c) Menyetorkan penerimaan yang diterima dari pihak ketiga ke rekening kas umum daerah paling lambat 1 hari kerja;

(d) Mendapatkan bukti transaksi atas pendapatan yang diterima melalui bank.

4). Bendahara penerimaan dalam melakukan penatausahaan atas penerimaan menggunakan:

(a) Buku Kas Umum;

(b) Buku rekapitulasi penerimaan bulanan;

(c) Surat Ketetapan Pajak Daerah (SKP-Daerah);

(d) Surat Ketetapan Retribusi (SKR);

(e) Surat Tanda Setoran (STS);

(f) Surat tanda bukti pembayaran; dan

(g) Buku penerimaan lainnya yang sah.

(5) Bendahara penerimaan pada SKPD wajib mempertanggungjawabkan secara administrasi atas pengelolaan uang yang menjadi tanggungjawab dengan menyampaikan laporan pertanggungjawaban penerimaan kepada pengguna

Published by: 
anggaran/kuasa pengguna anggaran melalui PPK-SKPD paling lambat tanggal 10 bulan berikutnya.

(6) Bendahara penerimaan pada SKPD wajib mempertanggungjawabkan secara fungsional atas pengelolaan uang yang menjadi tanggungjawab dengan menyampaikan laporan pertanggungjawaban penerimaan kepada pengguna anggaran/kuasa pengguna anggaran melalui PPKD selaku BUD paling lambat tanggal 10 bulan berikutnya.

(7) Laporan pertanggungjawaban penerimaan dilampiri dengan:

(a) Buku kas umum;

(b) Buku rekapitulasi penerimaan bulanan; dan

(c) Bukti penerimaan lainnya yang sah.

(8) Dalam hal obyek pendapatan daerah tersebar atas pertimbangan kondisi geografis wajib pajak/atau wajib retribusi tidak mungkin membayar kewajibannya langsung pada badan, lembaga keuangan atau kantor pos yang bertugas melaksanakan sbagian tugas dan fungsi bendahara penerimaan, dapat ditunjuk bendahara penerimaan pembantu.

(9) Bendahara penerimaan pembantu wajib menyelenggarakan penatausahaan terhadap seluruh penerimaan dan penyetoran atas penerimaan yang menjadi tanggung jawabnya.

(10) Penatausahaan atas penerimaan sebagaimana dimaksud pada angka menggunakan :

(a) Buku kas umum; dan

(b) Buku rekapitulasi penerimaan harian pembantu.

(11)Bendahara penerimaan pembantu dalam melakukan penatausahaan menggunakan:

(a) Surat Ketetapan Pajak Daerah (SKP- Daerah);

(b) Surat Ketetapan Retribusi (SKR);

(c) Surat Tanda Setoran (STS);

(d) Surat tanda bukti pembayaran; dan

(e) Bukti penerimaan lainnya yang sah.

(12)Bendahara peneriman pembantu wajib menyampaikan laporan pertanggungjawaban penerimaan kepada bendahara penerimaan paling lambat tanggal 5 bulan berikutnya;

(13)Bendahara peneriman pembantu wajib menyetor seluruh uang yang diterimanya ke rekening kas umum daerah paling lambat 1 (satu) hari kerja terhitung sejak uang kas tersebut diterima.

Published by:

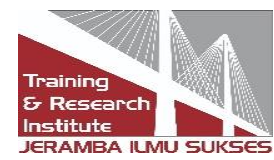


(14)Bendahara penerimaan pembantu mempertanggungjawabkan bukti penerimaan dan bukti penyetoran dari seluruh uang kas yang diterimanya kepada bendahara penerimaan.

(15) Kepala daerah dapat menunjuk bank, badan, lembaga keuangan atau kantor pos yang bertugas melaksanakan sebagian tugas dan fungsi bendahara penerimaan.

(16)Bank, badan, lembaga keuangan atau kantor pos menyetor seluruh uang yang diterimanya ke rekening kas umum daerah paling lambat 1 (satu) hari kerja terhitung sejak uang kas tersebut diterima.

(17)Bank, badan, lembaga keuangan atau kantor pos mempertanggungjawabkan seluruh uang kas yang diterimanya kepada kepala Daerah melalui BUD.

(18)Bendahara penerimaan PPKD bertugas untuk menatausahakan dan mempertanggungjawabkan seluruh penerimaan pendapatan PPKD dalam rangka pelaksanaan APBD.

(19) Untuk melaksanakan tugas di atas bendahara penerimaan PPKD berwenang untuk mendapatkan bukti transaksi atas pendapatan yang diterima melalui bank.

(20) Atas pertimbangan efisiensi dan efektifitas, tugas dan wewenang bendahara penerimaan PPKD dapat dirangkap oleh Bendahara Umum Daerah.

\section{Metode Penelitian}

Data yang digunakan dalam penelitian ini yaitu data primer yaitu data penelitian yang diperoleh langsung dari sumber wawancara langsung dengan pihak yang berkaitan dengan penelitian ini, dan data sekunder berasal dari objek penelitian biasanya berupa profil instansi dan dokumen-dokumen yang berkaitan dengan sistem akuntansi pendapatan yang diperoleh dari Badan Keuangan Daerah Kota Lubuklinggau

Metode pengumpulan data yang digunakan dalam penelitian ini adalah teknik wawancara, yaitu pengumpulan data dengan mengajukan pertanyaan-pertanyaan secara bebas baik terstruktur maupun tidak terstruktur dengan tujuan untuk memperoleh informasi secara luas mengenai sistem akuntansi pendapatan dengan dibantu salah satu pegawai di kantor Satuan Kerja Perangkat Daerah Badan Keuangan Daerah Kota Lubuklinggau dan teknik dokumentasi, mengumpulkan dokumen-dokumen yang berkaitan dengan Sistem Akuntansi Pendapatan SKPD pada Badan Keuangan Daerah Kota Lubuklinggau, buku-buku literatur, regulasi, jurnal, serta bahan-bahan informasi lainnya yang berhubungan dengan masalah yang diteliti.

Dalam penelitian ini analisis data yang akan digunakan adalah analisis kualitatif merupakan analisa nonsattistik yang membantu dalam penelitian, data yang diperoleh baik berupa angka maupun yang berupa tabel kemudian ditafsirkan dengan baik, datadata berupa teori-teori yang di maksud berguna untuk menjelaskan suatu fenomena yang terjadi.

Teknik analisis yang digunakan oleh penelitian ini adalah teknik analisis deskriftif yaitu

Published by:

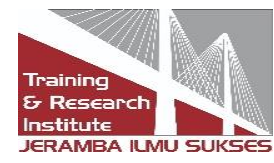


analisis data dengan cara menjelaskan teori-teori bukan angka yang berhubungan dengan masalah yang diteliti.

\section{Hasil dan Pembahasan}

Azas umum Sistem dan Prosedur Pengelolaan Keuangan Daerah salah satunya adalah keuangan Daerah dikelola secara tertib, taat pada peraturan perundang-undangan, efektif, efisien, ekonomis, transparan, dan bertanggungjawab dengan memperhatikan azas keadilan, kepatutan, dan manfaat untuk masyarakat. Berdasarkan hasil penelitian yang sudah dijabarkan diatas maka sistem akuntansi pendapatan pada Badan Keuangan Daerah Kota Lubuklinggau akan dibahas satu persatu sebagai berikut

1. Pihak yang Terkait

Berdasarkan hasil wawancara dengan Ibu Lisma Agustini, SE berkaitan dengan pihakpihak yang terkait dalam sistem akuntansi pendapatan pada Badan Keuangan Daerah sudah berjalan dengan baik, akan tetapi belum sepenuhnya sesuai dengan sistem dan prosedur pengelolaan keuangan daerah. pihak- pihak yang terkait dalam sistem akuntansi pendapatan pada Badan Keuangan Daerah akan dibahas satu persatu sebagai berikut:

a) Pengguna Anggaran/Kuasa Pengguna Anggaran (PA/KPA)

b) Pejabat Penatausahaan Keuangan Satuan Kerja Perangkat Daerah (PPK- SKPD)

c) Bendahara Penerimaan

d) Bendahara Penerimaan Pembantu

e) PPKD (Pejabat Pengelola Keuangan Daerah) selaku BUD

f) Pihak Ketiga

2. Dokumen Yang Terkait

Dokumen yang terkait dalam prosedur pendapatan-LRA secara umum terdiri dari Surat Ketetapan Pajak Daerah (SKP- Daerah), Surat Ketetapan Retribusi (SKR), Surat Tanda Bukti Penerimaan (STBP), Surat Tanda Setoran (STS), Bukti Transfer/Setor, Nota Kredit Bank, Bukti Memorial, dan Bukti transaksi Penerimaan Kas Lainnya.

Pelaksanaan penerimaan pendapatan daerah melalui Bendahara Penerimaan, meliputi Pengguna Anggaran menyerahkan SKP-Daerah/SKR kepada Bendahara Penerimaan dan Wajib Pajak/Retribusi, Wajib Pajak/Retribusi membayarkan sejumlah uang yang tertera dalam SKP Daerah/SKR kepada Bendahara Penerimaan, Bendahara Penerimaan memverifikasi uang yang telah diterimanya dengan SKP- Daerah/SKR yang diterimanya dari Pengguna Anggaran, setelah diverifikasi Bendahara Penerimaan akan menerbitkan STS dan Surat Tanda Bukti pembayaran/bukti lain yang sah, Bendahara menyerahkan tanda bukti pembayaran/bukti lain yang sah kepada Wajib Pajak/Retribusi dan menyerahkan uang yang diterimanya tadi beserta STS kepada bank, dan Bank membuat Nota Kredit dan mengotorisasi STS, Bank kemudian menyerahkan kembali

Published by: 
STS kepada Bendahara Penerimaan Nota Kredit disampaikan kepada Bendahara Umum Daerah (BUD).

Pelaksanaan penerimaan pendapatan daerah melalui Bendahara Penerimaan Pembantu, meliputi Pengguna Anggaran menyerahkan SKP-Daerah/SKR kepada Bendahara Penerimaan Pembantu, Wajib Pajak/Retribusi membayarkan uang kepada Bendahara Penerimaa Pembantu sejumlah yang tertera dalam SKP Daerah/SKR, Bendahara Penerimaan Pembantu memverifikasi uang yang telah diterimanya dengan SKPDaerah/SKR yang diterimanya dari Pengguna Anggaran, Jika sesuai maka Bendahara Penerimaan Pembantu membuat dokumen STS dan Surat Tanda Bukti pembayaran/bukti lain yang sah, Bendahara Penerimaan Pembantu menyerahkan surat tanda bukti pembayaran/bukti lain yang sah kepada Wajib Pajak/Retribusi dan STS beserta uang kepada bank, dan Bank mengotorisasi STS dan menerbitkan Nota Kredit. Bank mengembalikan STS kepada Bendahara Penerimaan Pembantu. Nota Kredit disampaikan kepada Bendahara Umum Daerah (BUD).

Apabila pelaksanaan penerimaan pendapatan daerah melalui Bank Pemerintah yang ditunjuk, Bank Lain, Badan, Lembaga Keuangan dan atau Kantor Pusat, dokumendokumen yang terkait meliputi Pengguna Anggaran menyerahkan SKP-Daerah/SKR kepada Wajib Pajak/Retribusi dan Bendahara Penerimaan, Wajib Pajak/Retribusi membayarkan uang kepada Bank Kasda sejumlah yang tertera dalam SKP Daerah/SKR, Bank Kasda menerbitkan slip setoran/bukti lain yang sah dan Nota Kredit, Bank kasda menyerahkan slip setoran/bukti lain yang sah kepada Wajib Pajak/Retribusi dan nota kredit kepada Bendahara Umum Daerah (BUD), dan Wajib Pajak Retribusi menyerahkan slip setoran/bukti lain yang sah kepada Bendahara Penerimaan.

Hasil penelitian berkaitan dengan dokumen-dokumen yang terkait dengan pendapatan Badan Keuangan Daerah Kota Lubuklinggau sudah sesuai teori sistem akuntansi pendapatan dan sesuai juga dengan aturan yang berlaku yaitu Peraturan Pemerintah Nomor 71 Tahun 2010 tentang Pedoman Pengelolaan Keuangan Daerah dan sudah mengacu pada Peraturan Walikota Lubuklinggau Nomor 63 Tahun 2016 tentang Sistem Akuntansi Pemerintah Daerah, Peraturan Menteri Dalam Negeri Republik Indonesia Nomor 64 Tahun 2013 tentang Penerapan Standar Akuntansi Pemerintahan Berbasis Akrual Pada Pemerintah Daerah

\section{Sistem dan Prosedur Akuntansi Pendapatan}

Sistem dan prosedur akuntansi pendapatan LRA pada Badan Keuangan Daerah Kota Lubuklinggau dalam pelaksanaannya dikelola oleh Pejabat Penatausahan Penerimaan Kas di SKPD meliputi sistem dan prosedur penatausahaan penerimaan kas dari pajak dan retribusi daerah melalui Bendahara Penerimaan, sistem dan prosedur penatausahaan penerimaan kas dari pajak dan retribusi daerah melalui Bendahara Penerimaan Pembantu, dan sistem dan prosedur penatausahaan penerimaan kas dari pajak dan retribusi daerah melalui Badan, Lembaga Keuangan, atau Kantor Pos yang ditunjuk oleh Pemerintah Daerah.

PPKD menyerahkan Surat Ketetapan Pajak (SKP) Daerah yang telah diterbitkan kepada Bendahara Penerimaan untuk keperluan melakukan verifikasi pada saat penerimaan pendapatan. Pengguna Anggaran menyerahkan Surat Ketetapan Retribusi (SKR) yang

Published by: 
telah diterbitkan kepada Bendahara Penerimaan untuk keperluan melakukan verifikasi pada saat penerimaan pendapatan.

Wajib Pajak/ Retribusi menyerahkan uang (setoran pajak/retribusi). Bendahara penerimaan kemudian melakukan verifikasi penerimaan uang dengan SKP Daerah/SKR yang bersangkutan. Setelah melakukan verifikasi, Bendahara Penerimaan mengeluarkan Surat Tanda Bukti Pembayaran/Bukti Lain yang Sah.

Bendahara Penerimaan menyiapkan Surat Tanda Setoran (STS). Bendahara Penerimaan kemudian melakukan penyetoran kepada bank disertai STS. STS yang telah diotorisasi oleh bank kemudian diterima kembali oleh Bendahara Penerimaan untuk kemudian menjadi bukti pembukuan.

Jurnal Penerimaan Kas di Bendahara Penerimaan.

Kas di Bendahara Penerimaan Rp 212.675,00

PBB Perdesaan dan Perkotaan - LO Rp 212.675,00

Perubahan SAL Rp 212.675,00

PBB Perdesaan dan Perkotaan - LRA Rp 212.675,00

(Setoran Pajak Bumi dan Bangunan)

Kas di Bendahara Penerimaan Rp 371.250,00

BPHTB - Pemindahan Hak - LO Rp 371.250,00

Perubahan SAL Rp 371.250,00

BPHTB - Pemindahan Hak - LRA Rp 371.250,00

(Setoran Pajak BPHTB (Pemindahan Hak))

Setoran Pajak Bumi dan Bangunan dan setoran pajak BPHTB (pemindahan hak) oleh Wajib Pajak pada Bendahara Penerimaan. Pada saat kas diterima oleh Bendahara Penerimaan, Bendahara Penerimaan membuat bukti penerimaankas saat kas diterima. atas bukti penerimaan tersebut maka PPK-SKPD mencatat jurnal seperti diatas. (Untuk Bukti Jurnal Penerimaan Kas terlampir).

Jurnal Penyetoran Uang dari Kas Bendahara Penerimaan ke Kas Daerah R/K PPKD Rp 212.675,00

Kas di Bendahara Penerimaan Rp 212.675,00 (Setoran Pajak Bumi Dan Bangunan) R/K PPKD Rp 371.250,00

Kas di Bendahara Penerimaan Rp 371.250,00 (Setoran Pajak BPHTB atau Pemindahan Hak)

Setoran Pajak Bumi dan Bangunan dan setoran pajak BPHTB (pemindahan hak) oleh Wajib Pajak yang diterima oleh Bendahara Penerimaan kemudian disetor ke Kas Daerah, atas penyetoran dari Bendahara Penerimaan ke Kas Daerah tersebut maka PPK-SKPD mencatat jurnal seperti diatas. (Untuk Bukti Jurnal penyetoran Kas terlampir)

Setiap Pendapatan Daerah diterima secara langsung di rekening Kas Daerah pada Bank.

Published by:

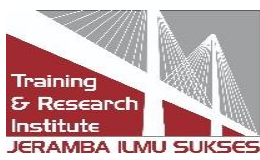


Pemerintah Pusat melakukan transfer dana berupa Pendapatan Dana Perimbangan ke Rekening Kas Daerah. Apabila dana tersebut di transfer ke rekening Kas Daerah pada Bank lain maka dana-dana tersebut akan dipindahkan ke rekening Kas Umum Daerah pada Bank. Pendapatan LRA diakui pada saat diterima pada Rekening Kas Umum Negara/Daerah. Pendapatan LRA diklasifikasikan menurut jenis pendapatan. Transfer masuk adalah penerimaan uang dari entitas pelaporan lain, misalnya penerimaan dana perimbangan dari pemerintah pusat dan dana bagi hasil dari pemerintah provinsi. Akuntansi Pendapatan LRA dilaksanakan atas dasar azas bruto, yaitu dengan membukukan penerimaan bruto, dan tidak mencatat jumlah netonya (setelah dikompensasikan dengan pengeluaran).

\section{Kesimpulan}

Pihak yang terkait dalam sistem akuntansi pendapatan pada lingkup SKPD adalah Pengguna Anggaran/Kuasa Pengguna Anggaran (PA/KPA),Pejabat Penatausahaan Keuangan SKPD (PPK- SKPD), Bendahara Penerimaan SKPD, BUD, dan Pihak Ketiga. Pihak yang terkait dalam sistem akuntansi pendapatan SKPD pada Badan Keuangan Daerah Kota Lubuklinggau masih ada yang belum sesuai dengan Peraturan Walikota Lubuklinggau Nomor 63 Tahun 2016 tentang Sistem Akuntansi Pemerintah Daerah yaitu belum ada pihak yang terkait Bendahara Penerimaan Pembantu, tetapi sudah mengacu pada Peraturan Pemerintah Nomor 71 Tahun 2010 tentang Pedoman Pengelolaan Keuangan Daerah Peraturan Menteri Dalam Negeri Republik Indonesia Nomor 64 Tahun 2013 tentang Penerapan Standar Akuntansi Pemerintahan Berbasis Akrual Pada Pemerintah Daerah.

Dokumen-dokumen yang terkait dengan sistem akuntansi pendapatan SKPD pada Badan Keuangan Daerah Kota Lubuklinggau yang terdiri dari Surat Ketetapan Pajak Daerah (SKP Daerah), Surat Ketetapan Retribusi (SKR), Surat Tanda Bukti Penerimaan (STBP), Surat Tanda Setoran (STS), Bukti Transfer/Setor, Bukti Memorial, dan Bukti transaksi Penerimaan Kas Lainnya. Dokumen-dokumen yang terkait sudah dicatat, dan dilaporkan sesuai dengan aturan yang berlaku yaitu Peraturan Pemerintah Nomor 71 Tahun 2010 tentang Pedoman Pengelolaan Keuangan Daerah dan sudah mengacu pada Peraturan Walikota Lubuklinggau Nomor 63 Tahun 2016 tentang Sistem Akuntansi, Peraturan Menteri Dalam Negeri Republik Indonesia Nomor 64 Tahun 2013 tentang Penerapan Standar Akuntansi Pemerintahan Berbasis Akrual Pada Pemerintah Daerah.

Sistem akuntansi pendapatan pada lingkup Satuan Kerja Perangkat Daerah (SKPD) Badan Keuangan Daerah Kota Lubuklinggau yang meliputi sistem dan prosedur penatausahaan penerimaan kas dari pajak dan retribusi daerah melalui Bendahara Penerimaan, sistem dan prosedur penatausahaan penerimaan kas dari pajak dan retribusi daerah melalui Bendahara Penerimaan Pembantu, dan sistem dan prosedur penatausahaan penerimaan kas dari pajak dan retribusi daerah melalui Badan, Lembaga Keuangan, dan atau Kantor Pos yang ditunjuk Pemerintah Daerah sudah sesuai dengan Peraturan Pemerintah Nomor 71 Tahun 2010 tentang Pedoman Pengelolaan Keuangan Daerah dan sudah mengacu pada Peraturan Walikota Lubuklinggau Nomor 63 Tahun 2016 tentang Sistem Akuntansi, Peraturan Menteri Dalam Negeri Republik Indonesia Nomor 64 Tahun 2013 tentang Penerapan Standar Akuntansi Pemerintahan Berbasis Akrual Pada Pemerintah Daerah.

Published by:

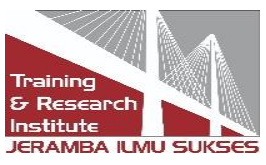




\section{Referensi}

Danang Sunyanto. 2016. Methodologi Penelitian Akuntansi. Bandung: PT Rafika Aditama

Hery. 2012. Mengenal dan Memahami Laporan Keuangan. Cetakan Pertama. Jakarta: CAPS (Center for Academic Publishing Service).

Iman, Santoso. 2010. Akuntansi Keuangan Menengah. Bandung : PT. Refika Aditama.

Indah Natalia Anthoni. 2016. Evaluasi Penerapan Akuntansi Pemerintah Untuk Pendapatan Asli Daerah Pada Dinas Pendapatan Pengelolaan Keuangan dan Aset Daerah (DPPKAD) Kabupaten Kepulauan Sanghie Periode 2014. Jurnal EMBA. Vol.4 No.1 Maret 2016. Hal. 1229- 1240.Jurusan Akuntansi. Universitas Sam Ratulangi Manado: Fakultas Ekonomi dan Bisnis.

Indra Bastian. 2010. Akuntansi Sektor Publik, Suatu Pengantar. Jakarta: Penerbit Salemba Empat.

Jeane M, Hendrik M, dan Victoria ZT. 2015. Evaluasi Penerapan Sistem Akuntansi Penerimaan Pendapatan Asli Daerah Pada Pemerintah Kabupaten Kepulauan Sangihe. Jurnal Berkala Ilmiah Efisiensi. Volume 15 No.03. Jurusan Akuntansi. Universitas Sam Ratulangi Manado: Fakultas Ekonomi dan Bisnis.

Keputusan Menteri Kesehatan Republik Indonesia Nomor 1981 Tahun 2010 (online), (http://rsud.indramayukab.go.id diakses pada 10 Oktober 2016).

Mahmudi. 2013. Akuntansi Sektor Publik. Ceakan Kedua. Yogyakarta: UII Pres Yogyakarta

Martani Dwi, dkk. 2012. Akuntansi Keuangan Menengah Berbasis Psak. Jakarta : Selemba Empat.

Muindro. Renyowijoyo. 2013. Akuntansi Sektor Publik, Organisasi Non Laba. Edisi Tiga. Jakarta: Penerbit Mitra Wacana Media.

Mulyadi. 2013. Sistem Akuntansi. Cetakan kelima. Jakarta: Salemba Empat.

Peraturan Menteri Dalam Negeri Republik Indonesia Nomor 59 Tahun 2007. Tentang Pedoman Pengelolaan Keuangan Daerah.

Peraturan Menteri Dalam Negeri Republik Indonesia Nomor 64 Tahun 2013. Tentang Penerapan

Standar Akuntansi Pemerintahan Berbasis Akrual Pada Pemerintah Daerah.

Peraturan Pemerintah Republik Indonesia. Nomor 71 Tahun 2010. Pernyataan Standar Akuntansi

Pemerintahan Nomor 02 ( laporan realisasi anggaran). (online), (http:www.ksap.org diakses pada 12 November 2016).

Peraturan Walikota Lubuklinggau Nomor 32. 2012. Sistem dan Prosedur Pengelolaan Keuangan Daerah. Lubuklinggau: Pemerintah Kota Lubuklinggau.

Peraturan Walikota Lubuklinggau Nomor 34. 2016. Penjabaran Tugas Pokok dan Fungsi Badan Keuangan Daerah. Lubuklinggau: Pemerintah Kota Lubuklinggau.

Published by: 
Peraturan Walikota Lubuklinggau Nomor.63 2016. Sistem Akuntansi. Lubuklinggau: Pemerintah Kota Lubuklinggau.

Rone Lucia Karamoy. 2013. Evaluasi Pelaksanaan Sistem Dan Prosedur Penerimaan Kas Di Dinas Pendapatan Kota Manado. Jurnal EMBA 939 Vol.1 No.3 Juni 2013, Hal. 939948.Fakultas Ekonomi Jurusan Akuntansi.Universitas Sam Ratulangi Manado.

Sugiyono. 2012. Metode Penelitian Pendidikan (Pendekatan Kuantitatif, Kualitatif, dan $R \& D)$.

Sugiyono, 2013. Metode Penelitian Administrasi. Bandung : Alfabeta, CV

\section{Copyrights}

Copyright for this article is retained by the author(s), with first publication rights granted to the journal.

This is an open-access article distributed under the terms and conditions of the Creative Commons Attribution license (http://creativecommons.org/licenses/by/4.0/)

Published by: 